International Journal of Economics, Business and Accounting Research (IJEBAR)

Peer Reviewed - International Journal

Vol-3, Issue-4, 2020 (IJEBAR)

E-ISSN: 2614-1280 P-ISSN 2622-4771

https://jurnal.stie-aas.ac.id/index.php/IJEBAR

\title{
ENCOURAGING BEHAVIOR SUPPORT TO CHANGE: THE ROLE OF INDIVIDUAL READINESS TO CHANGE AND COMMITMENT TO CHANGE
}

\author{
Dwi Indriastuti, Olivia Fachrunnisa \\ Department of Master Management, Faculty of Economics, Sultan Agung Islamic University \\ Semarang, Indonesia \\ Email: dwiindriastuti.y@std.unissula.ac.id_olivia.fachrunnisa@unissula.ac.id
}

\begin{abstract}
Abstrack: $\quad$ Every organization are required to be able to respond the competitive world and globalization; it causes an increasing need of qualified employees. This forces organization to manage employees to have adaptive and supportive behavior towards change. The aim is to examine the role of individuals' readiness to change, changeoriented leadership, and commitment to change toward behavior support to change. The results show to encourage behavior supports to change, influenced by commitment to change, individual readiness to change and support from leader who have a changeoriented leadership.

Keywords: $\quad$ change-oriented leadership; individual readiness to change; commitment to change; behavior support to change
\end{abstract}

\section{Introduction}

Organizations in order to survive, both in the short and long term in a competitive world like today, must be able to adapt to the changes that occur in the external environment, in which one method is by growing employees' responsibility to support change. The existence of environmental changes, along with the times, and new needs, requires individuals and organizations to embrace the change and answer these challenges for maintaining their existence, (Khasali, 2007).

Workforces are considered as critical factors that contribute to organizational success. Therefore, effective management of workforces is important for every organization (Juhdi, Pa'wan \& Othman 2011). In addition, research shows that the important variable in terms of successful change is people, because without the support of the individuals in it, any change program that is developed cannot be achieved successfully. Hence, the readiness of individuals to change is needed, however, the readiness of individuals is not enough for organizational change, they must also be willing to commit to change (Herscovitch \& Meyer, 2002). Individual readiness in dealing with change, and individual commitment to change becomes important as it will influence the attitudes and behavior of individuals to support these changes.

Nothing in this world lasts forever, including humans, every individual will change, not only physically but also behaviorally. Lewin (1997) argues that human behavior is a balanced state between driving forces and restraining forces. This behavior can change if there is an imbalance between the two forces within a person. However, these changes do not automatically occur in the desired direction, this is where the role of management to regulate and encourage changes in individual behavior towards the expected organizational goals happens. The success in carrying out organizational transformation cannot be separated from the behavior of individuals and management in implementing and making efforts to change in a sincere and harmonious manner. The success of the change is marked by an increase in employee behavior that supports the change so that the change can proceed as expected. Change management can contribute to turning a negative situation into a positive one. This is a success for the organization as a whole (Fumasoli \& Stensaker, 2013).

According to Armenakis, Harris \& Mossholder (1993), changes made by organizations will not succeed without individual changes in them, employee changes will not be effective without being 
International Journal of Economics, Business and Accounting Research (IJEBAR)

Peer Reviewed - International Journal

Vol-3, Issue-4, 2020 (IJEBAR)

E-ISSN: 2614-1280 P-ISSN 2622-4771

https://jurnal.stie-aas.ac.id/index.php/IJEBAR

prepared in advance, and so that readiness for change is not merely premature, the first must changed is the person (people), then the technical / method aspects (Prochaska, J., \& DiClemente, C.1984). Added by Blackman, Buick, O’Donnell, O'Flynn, \& West (2013) that in the total organizational change the stages that need to be changed first are change based on human potential, next is change based socio technical. This indicates that the people aspect is the first priority in the change followed by the method aspect. This aspect is very important because it will greatly affect the "behavior" of the individual, especially the behavior to change. Individuals who are ready to change believe that the organization will progress if the organization makes changes, has a positive attitude towards organizational change and has a desire to be involved in implementing organizational change (Armenakis, Harris \& Mossholder, 1993).

Another factor that is considered to influence individual behavior towards change is commitment to change. Individuals who are more committed will be more likely to embrace change than those who are less committed. It is also reinforced by the statements of Visagie and Steyn (2011) which reveal that commitment can influence a person's behavior to change. An understanding of the ways that can be used to encourage behavior that supports change is necessary to prepare employees to support these changes. Commitment can be one of the ways that organizations can use to encourage employee's behavior to change and solve the problems of resistance to change (Cummings \& Worley, 2001). However, workforces's commitment to change will not occur without the support of the leader. Therefore, in this study we also propose that the support from the leaders who has change-oriented leadership as one of the main drivers for individual readiness to change and employee commitment to change.

Support from the leaders is one of the factors that influence the readiness of individuals to change as leaders have an important role in the implementation of organizational change (Mullins, 2005), because leaders can influence and direct their followers in achieving organizational goals. In special situations a leader requires a special type of leadership. The qualities of the leader must be in accordance with the needs of the organization concerned. Leadership in the process of organizational change can affect the success of the change that will be achieved by the organization. In the pre-existing literature, there is still a lack of specificity in the leadership style possessed by leaders who have a high orientation to keep organizational change dynamic and adaptive. Therefore, we believe that change-oriented leadership is one of the important factors needed by organizations that are undergoing a change process, because it will affect the success of the change process in the organization. This leadership is believed to be able to direct and oversee organizational change to achieve its goals.

This research was conducted to test an empirical model of behavior on organizational member in supporting organizational change. In addition, this study also wants to contribute theory related to the importance of the role of change-oriented leadership to encourage behavior that supports change by mediating factors in the readiness of individuals to change and is associated with commitments to change. It causes the research about the relationship between these variables is still rare.

\section{Literature Review and Hypotheses Development Change Oriented Leadership}

Leadership is a factor that is often discussed widely, because both government and community organizations are increasingly aware that the achievement of national, regional or local goals depends on leadership. The definition of leadership is based on the assumption that leadership can influence and direct employees, facilitate the activities and relationships of employees in a group or organization (Yukl, 2013). The effectiveness of a leader is determined by his ability to influence and direct its members. An organization will succeed or fail is largely determined by leadership. A leader in comparison to other leaders will have different style, character, traits and personalities. In special situations a leader always requires a special type of leadership. The qualities of the leader must be in accordance with the needs of the organization concerned and in accordance with the existing situation. Hence, it can be concluded that 
International Journal of Economics, Business and Accounting Research (IJEBAR)

Peer Reviewed - International Journal

Vol-3, Issue-4, 2020 (IJEBAR)

E-ISSN: 2614-1280 P-ISSN 2622-4771

https://jurnal.stie-aas.ac.id/index.php/IJEBAR

the success of an organization is largely determined by leadership. Muafi, Fachrunnisa, Siswanti, et al (2019) state that leadership has positive impact on employee engagement, changed oriented leadership will inspire the employees to be ready to face change and will deliver beliefs that employee who are ready to face the change will have higher performance than those who do not.

The global world changes rapidly, it requires organizations to continue to change according to the dynamics and demands of the times. Organizational change strongly emphasizes the role of the main leadership, especially leadership that is also oriented to change (Armenakis, Harris \& Mossholder, 1993).. Change-oriented leadership is a leader who is able to identify the organizational threats and opportunities in the future, able to make strategies and build new visions, encourage subordinates to be creative and innovative, and, have a creative attitude and offer new ideas, and able to take risks to significant change progress (Yukl, 2002).

It can be concluded that, change-oriented leadership plays an important role in achieving the effectiveness of the change process in organizations. Therefore, change-oriented leadership is related to the ability to build cooperative relationships with other organizations, and have confidence in dealing with new things. Moreover, change-oriented leadership will also influence and direct employees to be ready to face the change.

\section{Individual Readiness to Change}

In the organizational context, the readiness of individuals to change is defined as the degree of individuals are prepared to participate in different organizational activities (Huy, 1999). An individual's readiness to change is seen as a precursor to the behavior of either resistance, or supporters of the change effort made by an organization (Armenakis, Harris, \& Mossholder, 1993). Previous research supports that an organization's individual readiness to make changes is the beginning for successful change (Armenakis, Harris, \& Mossholder, 1993). In addition, the target element of change places the human element (people) as the central element, outside the method, social, organizational, and objective factors.

A study conducted by Desplaces (2005) states that the readiness of individuals to deal with change will be the driving force to make changes that provide positive results. Recent research on the variable of individuals' readiness to change explains that an individual's readiness to change can actually be identified through an individual's positive attitude towards change, whether work methods and work procedures felt by individuals support change, perceptions of members of the organization as a whole to deal with change, and self-confidence for individuals to face the change. Individual attitudes toward change can be seen from individual responses to these changes, whether they accept or reject changes. Furthermore, the readiness of individuals to deal with change will affect the mindset, feelings, and attention of individuals as reflected in their attitudes and behavior. Individual readiness to change is also strongly influenced by beliefs where they have the ability to show new behavior (Desplaces, 2005).

\section{Commitment to Change}

Coetsee (1999) argues that if employee attitude towards organizational change is positive, it can be said that there is commitment. Commitment to the organization contributes to employee motivation, improves employee performance, reduces absenteeism and ensures that employee turnover rates remain at a minimum level. The same opinion was expressed by Kreitner, Robert \& Kinicki (2014) which states that commitment is an agreement to do something for yourself, others, groups or organizations.

During organizational change, many individuals feel they are in uncertainty and experience anxiety about potential failures in handling new work situations (Cummings \& Worley, 2014). These attitudes and behaviors can influence employee commitment to organizational change and its relationship with behavioral support to support change. Therefore, commitment is one of the most important factors involved in shaping employee behavior to support change (Armenakis, Feild, Holt \& Harris, 2007). 
International Journal of Economics, Business and Accounting Research (IJEBAR)

Peer Reviewed - International Journal

Vol-3, Issue-4, 2020 (IJEBAR)

E-ISSN: 2614-1280 P-ISSN 2622-4771

https://jurnal.stie-aas.ac.id/index.php/IJEBAR

There are three components of commitment to change are as follows: (1) Affective commitment to change: the desire to provide support for change based on his belief in inherent benefits. In other words, affection is held for work or when there are strong feelings and emotional attachment to the work done.

(2) Continuing commitment to change: recognition that there are costs associated with failing to provide support for change, fear of losing your job / income, and (3) Normative commitment to change: feeling a moral responsibility to provide support for change to the organizations that employ it. Commitment to change will eventually shape the behavior to support this change according to the research conducted by (Jones, 2005) conclude that commitment to change has a positive relationship with behavior support to change.

\section{Behavior Support to Change}

Employee behavior is the interaction between employee with employee or employee with their environment. The behavior of each employee is strongly influenced by the environment in which the employee is located. While organizational behavior is largely determined by the behavior of employee in the organization (Luthan, 2009). According to Herscovitch and Meyer (2002), there are three types of behavior that support change: compliance, cooperation and championing. Behavior support to change is defined as a set of behaviors carried out by employees who feel attached to the organization, feel obliged to perform a series of behaviors that are relevant to the success of change.

Compliance refers to the willingness of employees to do what is asked of them by the organization in implementing change. Cooperation refers to the acceptence of employees to the "spirit" of change and the willingness to do a little extra to make it work. Finally, championing refers to the willingness of employees to accept changes and "sell" them to others (Herscovitch \& Meyer, 2002).

Behavior support to change in the organization includes behaviors that are expected to be done by employees as a form of support for changing in the organization. Employees as recipients of change are expected to be able to carry out a series of change processes in accordance with those applied by management so that the expected performance is achieved. Change that is applied through behavior to be as expected is one indicator of the success of organizational change.

\section{Change-Oriented Leadership and Individual Readiness to Change}

Change-oriented leadership is also an important factor in the process of organizational change, since with good leadership a leader will be able to provide direction and encouragement to employees to be able to deal with changing times and the rapid development of technology. Armenakis, Harris, \& Mossholder, 1993 argue that leaders who act as coaches and who fight for change will be more successful in preparing employees for change efforts than leaders who only pay attention to a handful of people who are resistant to change. In addition, good leadership can also empower employees to complete work and can encourage the confidence of employees in dealing with changes so that employees become better prepared to deal with these changes.

In addition, the leader must be able to communicate changes well to employees in order to be able to foster acceptance and trust in the changes that have been proposed. The trust of employees towards leaders and knowing that leaders also support change efforts is very important to ensure employee readiness to change. Research by Qais, Rezian-na, Valliapan, Ali, \& Muhammed, A. (2018) concluded that there is a significant correlation between top management factors in this case leadership with the readiness of individuals to change. From the previous studies it can be concluded that change-oriented leadership has an influence on the readiness of individuals to change, hence we propose the following hypothesis:

H1: The existence of change-oriented leadership will encourage individual readiness to change 
International Journal of Economics, Business and Accounting Research (IJEBAR)

Peer Reviewed - International Journal

Vol-3, Issue-4, 2020 (IJEBAR)

E-ISSN: 2614-1280 P-ISSN 2622-4771

https://jurnal.stie-aas.ac.id/index.php/IJEBAR

\section{Individual Readiness to Change and Commitment to Change}

In addition to having readiness to change, individuals are also encouraged to have a high commitment to change. This is in accordance with the opinion of Corner (1992) who argued that to get an individual's commitment to change, the individual readiness factor is very important in supporting the success of a change initiative because this is the individual who will be directly affected by the change in the organization. According to Weiner (2009) organizational readiness to change refers to organizational commitment of members to change and their confidence to implement organizational change. This is also consistent with Lewin's opinion (1947) which proposes that for change to be successful, it is important that negative attitudes toward change should be overcome to avoid rejection of change. Whereas Armenakis, Harris, \& Mossholder (1993) suggested that for changes to be successful employees need to be prepared in advance, change agents must strive to change the beliefs and understandings of employees who will be involved in the change process.

The positive individual's mindset and belief in the purpose and objectives of the change process are also important determinants of the success of a transformation. Armenakis, Achilles, Bernerth, Jeremy, Pitts, Jennifer \& Walker (2017) argues that management must prepare employees to change through open and honest communication. The clearer the information received by the employee will make the individual more ready and more confident about the change, so the change process will run more effectively. It can then be concluded that the more the employee understands and believes in the benefits of change the more ready the employee to change and the employee will also be more confident to commit.

Research conducted by Al-Abrrow (2013) shows the results that the readiness of individuals to change has a positive and significant effect on individual commitment to change. From the previous studies it can be concluded that the readiness of individuals to change has an influence on commitment to change, so we propose the following hypothesis:

H2: Individuals who are ready to change will have a positive relationship with commitment to change

\section{Individual Readiness for Change and Behavior Supporting Change}

An individual's readiness to change is indicated by the intention, but the intention is related to motivational factors that will later be able to influence a person's behavior, and is an indicator for that person about how much he has tried and how much effort he wants to make for the change process (Ajzen, 1991). Individual readiness to change is shown by one's feelings and ability to achieve change, willing to participate in the process of change and willing to support and contribute to organizational change (Armenakis, Harris, \& Mossholder, 1993).

Employee will have the behavior support to change if the employee has goals that are aligned with the goals of organizational change. While (Armenakis, Harris, \& Mossholder, 1993) defines readiness to change as the involvement of the trust and desire of organizational members regarding how much support for the change must be made, their perception of the capacity of individuals and organizations to achieve the success of these changes. Organizational members' perceptions of change will determine the effectiveness of the change effort where this perception will affect the attitudes and behaviors of organizational members to make changes. From some of the previous studies it can be concluded that the readiness of individuals to change has an influence on behavior to support change, so we propose the following hypothesis:

H3: Individuals who are ready to face change will have a positive relationship with behavior support to change 
International Journal of Economics, Business and Accounting Research (IJEBAR)

Peer Reviewed - International Journal

Vol-3, Issue-4, 2020 (IJEBAR)

E-ISSN: 2614-1280 P-ISSN 2622-4771

https://jurnal.stie-aas.ac.id/index.php/IJEBAR

\section{Commitment to change and behavior support to change}

Commitment to change is a powerful mindset that binds individuals to take actions and attitudes that are deemed necessary for the successful implementation of change initiatives (Herscovitch \& Meyer, 2002). In addition, Kreitner \& Kinichi (2014) states that commitment is an agreement to do something for yourself, others, groups or organizations. Employee commitment to change can also be said as an impetus for someone to take a series of actions aimed at implementing and succeeding the implementation and initiative of change (Gelaidan, 2013). In other words, one of the challenges of the organizational change process is keeping their employees committed throughout the change process, so that they have an attitude that will support change.

When one's attitude towards organizational change is positive, it can be said that there is commitment (Coetsee, 1999). Employee commitment to change will affect organizational behavior as indicated by their employees. Some literature confirm that commitment is one of the most important factors influencing employee behavior support to change (Armenakis, Feild, Holt \& Harris, 2007).

Commitment to change includes understanding and trust of employees towards the good goals to be achieved by the organization so that employees earnestly make efforts to achieve organizational goals. Achieving the goals of organizational change is also expected to be able to increase the opportunities for employees to achieve their goals within the organization. Employees with high commitment to change tend to have behaviors to support change, this is in accordance with research conducted by (Jones, 2007) where that commitment to change has a positive relationship with behavior that supports change. From some of the previous studies it can be concluded that individual commitment to change has an influence on behavior support to change, so we propose the following hypothesis:

H4: Commitment to change has a positive relationship with the readiness of individuals to change

Based on various theoretical studies and previous studies, the empirical model of this research is presented in Figure 1.

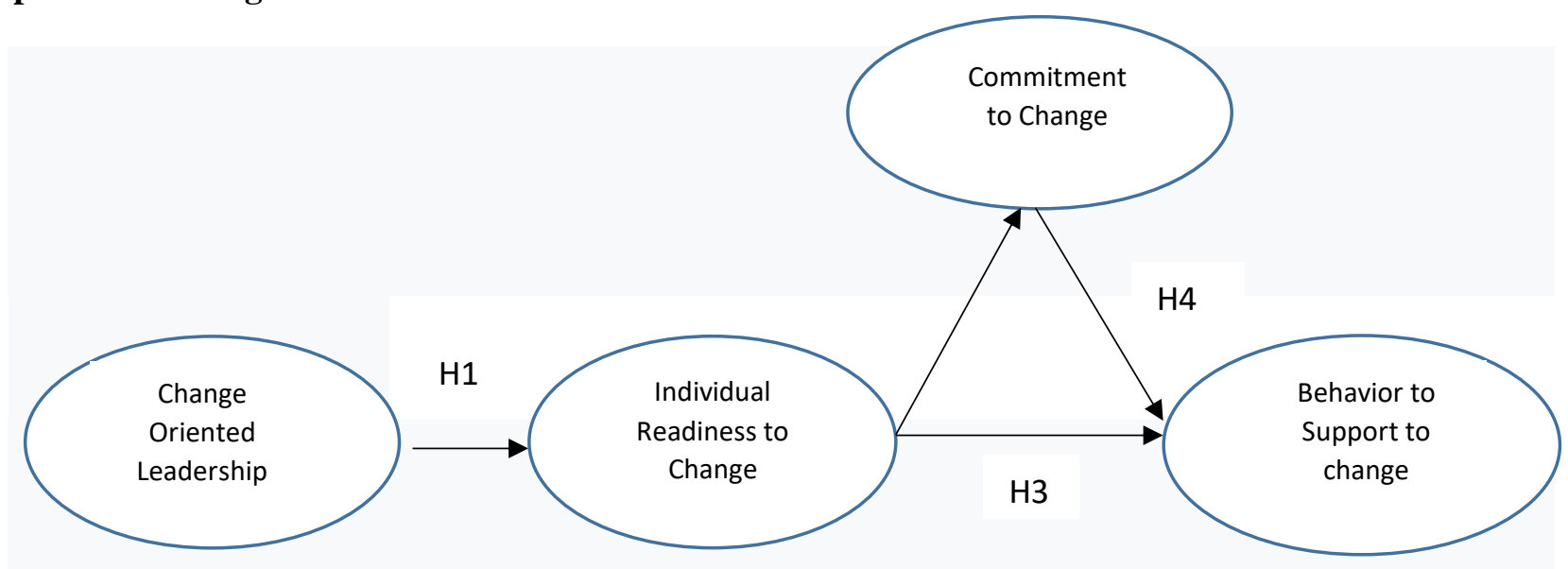

Figure 1.

Empirical Research Model 
International Journal of Economics, Business and Accounting Research (IJEBAR)

Peer Reviewed - International Journal

Vol-3, Issue-4, 2020 (IJEBAR)

E-ISSN: 2614-1280 P-ISSN 2622-4771

https://jurnal.stie-aas.ac.id/index.php/IJEBAR

3. Methodology

Population, sample, and measurement

The population of this study were all the employees of Statistics Central Bereau of Central Java Province, Indonesia. The selection of this research sample is based on the consideration that Statistics Central Bereau of Central Java Province is considered a role model for 35 Statistics Central Bereau District/City Offices below. The number of samples to be examined in this study in total are116 employees. The respondents are employees at Statistics Bereau of Central Java Province, Indonesia, it is an institution that handles public and sectoral statistics, this institution has been and is undergoing on a process of initiating change over the past five years especially the changes on the core values of organization.

Data was collected through questionnaire distribution with the categories of open questions and closed questions. Choice of response answers given to respondents using one type of attitude scale is the Likert scale. The Likert scale used in this study uses five response points represented by numbers 1-5 with number 1 representing strongly disagree and number 5 representing strongly agree, while open questions serve to confirm closed questions

Data were analyzed with Structural Equation Modeling (SEM) using the Lisrel 8.8 program, to determine the relationship between variables and test the hypotheses. It then followed by Sobel Test to test the role of mediation variables.

\section{Measurements}

Change Oriented Leadership

We define change-oriented leadership as leadership that is able to promote change, and is able to foster organizational growth, as well as generate new ideas in completing work. The indicators we use to measure this variable are as follows: the leader is able to explain to subordinates the importance of following changes and developments, encouraging subordinates to think creatively and find new solutions in completing work, understanding organizational opportunities and challenges in the future, willing to take risks and be able to take the right and fast decisions related to organizational change, and be able to build cooperative relationships with other organizations / agencies (Yulk, Gordon, Taber, 2002).

\section{Individual Readiness to Change}

We define an individual's readiness to change as an individual's positive attitude towards change, support for organizational change, and confidence in the face of change. The indicators we used to measure the variables of individual readiness to change are the readiness of individuals in facing changes marked by the desire to progress for the better, attitudes that support the existence of new ways of working, the willingness to follow new knowledge and technology, the willingness to work better with new work procedures, and have confidence in dealing with changes (Desplaces, 2005).

\section{Commitment to Change}

Commitment to change is defined as the drive that binds an individual to a series of actions aimed at implementing and succeeding the implementation and initiative of change. This variable is measured using three indicators namely affective commitment to change, continual commitment to change and normative commitment to change. Affective commitment to change is the desire to provide support for change based on the inherent benefits, the presence of love and emotional attachment to the work done. Continuous commitment to change is the desire to provide support for change because of fear of reduced income and loss of work, if the change process fails. Normative commitment to change is the desire to provide support for change, because there is a moral obligation and responsibility to provide support for change to the organizations that have employed it (Herscovitch and Meyer, 2002). 
International Journal of Economics, Business and Accounting Research (IJEBAR)

Peer Reviewed - International Journal

Vol-3, Issue-4, 2020 (IJEBAR)

E-ISSN: 2614-1280 P-ISSN 2622-4771

https://jurnal.stie-aas.ac.id/index.php/IJEBAR

\section{Behavior Support to Change}

Behavior support to change is defined as behavior that is expected to be carried out by employees as a form of support and efforts towards achieving organizational change goals. The indicators we use to measure these variables are: compliance, cooperation and championing. Compliance is the willingness of employees to do what is asked of them by the organization in implementing organizational change. Cooperation is the willingness of employees to accept the "spirit" of change and want to provide input for the success of organizational change. Championing / fighting is the willingness of employees to fight for change and sell it to others so they want to change (Herscovitch and Meyer, 2002).

\section{Results and Findings}

\section{Initial Estimation Analysis}

All indicators observed in this study have good validity and reliability values, the value of construct reliability (CR) is greater than 0.70 and the extracted variance value (VE) is greater than 0.50 . Therefore, all observable indicators are included in the next SEM model.

\section{Overall Model Fit Test}

The overall model fit test is a comprehensive assessment of the fit (Goodness of Fit) between the data and the model, can be seen in Table 1.

Table 1 Overall Model Test Result

\begin{tabular}{|c|c|c|c|c|}
\hline No. & $\begin{array}{c}\text { GOF } \\
\text { Measurement }\end{array}$ & Match Level target & Estimation Result & Goodness of Fit \\
\hline (1) & $(2)$ & (3) & (4) & (5) \\
\hline 1. & $\begin{array}{l}\text { Chi-Square } \\
\text { p-value }\end{array}$ & $\begin{array}{l}\text { Small value } \\
p>0.05\end{array}$ & $\begin{array}{l}\text { Chi-Square }=19,29 \\
\mathrm{p}=0.0\end{array}$ & Not good \\
\hline 2. & RMSEA & RMSEA $\leq 0.08$ & RMSEA $=0.19$ & Not good \\
\hline 3. & RMR & Standardized RMR $\leq 0.05$ & 0.05 & Good \\
\hline 4 & GFI & GFI $\geq 0.90$ & 0.93 & Good \\
\hline 5. & AGFI & $\mathrm{AGFI} \geq 0.90$ & 0.64 & Good \\
\hline 6. & CFI & $\mathrm{CFI} \geq 0.90$ & 0.98 & Good \\
\hline 7. & IFI & IFI $\geq 0.90$ & 0.98 & Good \\
\hline 8. & RFI & RFI $\geq 0.90$ & 0.92 & Good \\
\hline 9. & PNFI & PNFI $\geq 0.90$ & 0.32 & Not Good \\
\hline 10. & PGFI & $\mathrm{PGFI} \geq 0.90$ & 0.19 & Not Good \\
\hline 11 & ECVI & $\begin{array}{l}\text { Small value and close to } \\
\text { ECVI saturated }\end{array}$ & $\begin{array}{l}\mathrm{M}^{*}=0,23 \\
\mathrm{~S}^{*}=0,17 \\
\mathrm{I}^{*}=3,30\end{array}$ & Good \\
\hline 12 & AIC & $\begin{array}{l}\text { Small value and close to } \\
\text { AIC saturated }\end{array}$ & $\begin{array}{l}M^{*}=25,92 \\
S^{*}=20,00 \\
I^{*}=379,81\end{array}$ & Good \\
\hline 13. & CAIC & $\begin{array}{l}\text { Small value and close to } \\
\text { CAIC saturated }\end{array}$ & $\begin{array}{l}M^{*}=55,95 \\
S^{*}=57,54 \\
I^{*}=394,82\end{array}$ & Good \\
\hline 14 & NFI & $\mathrm{NFI} \geq 0.90$ & 0,97 & Good \\
\hline 15 & NNFI & $\mathrm{NNFI} \geq 0.90$ & 0,94 & Good \\
\hline
\end{tabular}


International Journal of Economics, Business and Accounting Research (IJEBAR)

Peer Reviewed - International Journal

Vol-3, Issue-4, 2020 (IJEBAR)

E-ISSN: 2614-1280 P-ISSN 2622-4771

https://jurnal.stie-aas.ac.id/index.php/IJEBAR

From the 15 GOF sizes, there are 4 GOF sizes that are not good and 11 GOF sizes have a good match, so it can be concluded that the overall fit of the model is good. SEM does not have any of the GOF measures that can be used as a basis for evaluating the suitability of the whole model, but rather considers several existing GOF measures (Hair et al, 2010).

\section{Relationship of the Variables}

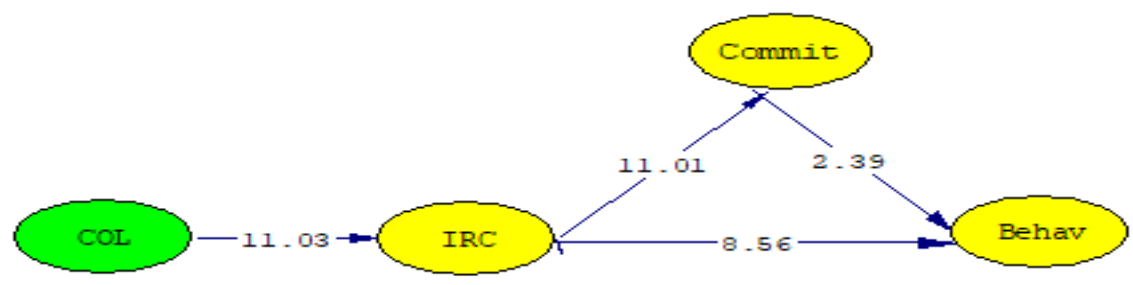

Figure 2. Path diagram shows the relationship between Change Oriented Leadership, Individual Readiness to Change, and Commitment to Change to Behavior to support to change. The structural equation as follows:

Equation (1) $\quad \mathrm{IRC}=0.74 * \mathrm{COL}$, Errorvar. $=0.45, \mathrm{R}^{2}=0.54$

Std deviasi (0.067) (0.068)

t-value $11.03 \quad 6.67$

Equation (2) Commit $=0.73 *$ IRC, Errorvar. $=0.47, \mathrm{R}^{2}=0.53$

Std deviasi (0.066) (0.072)

t-value 11.01

Equation (3) Behav $=0.70 * \mathrm{IRC}+0.22 *$ Commit, Errorvar. $=0.24, \mathrm{R}^{2}=0.75$

Std deviasi $(0.081) \quad(0.091) \quad(0.048)$

t-value $\quad 8.56 \quad 2.39 \quad 5.11$

Hypothesis 1 of this research is the existence of change-oriented leadership will encourage the readiness of individuals to change. The path parameter coefficient obtained from the relationship between change oriented leadership variables on Individual Readiness to change is 0.74 with $\mathrm{t}$-statistic value 11.03 . At a significance level of alpha 0.05 and 95 percent confidence level it can be said that there is a significant influence between change-oriented leadership on individual readiness to change. The positive value of the parameter coefficient means the better change-oriented leadership will increasingly encourage individual readiness in dealing with change. So that hypothesis 1 is supported.

Hypothesis 2 of this study is that individuals who are ready to change will have a positive relationship with commitment to change. The path coefficient obtained from the relationship between the individual variables readiness to change to commitment to change is 0.73 with a t-statistic value of 11.01 . At a significance level of alpha 0.05 and 95 percent confidence level it can be said that there is a significant effect between individual readiness to change on commitment to change. Positive coefficient parameter 
International Journal of Economics, Business and Accounting Research (IJEBAR)

Peer Reviewed - International Journal

Vol-3, Issue-4, 2020 (IJEBAR)

E-ISSN: 2614-1280 P-ISSN 2622-4771

https://jurnal.stie-aas.ac.id/index.php/IJEBAR

means that the more ready the individual to change, the higher the commitment to change. As a result, hypothesis 2 is supported.

Hypothesis 3 of this study, individuals who are ready to deal with change will have a positive relationship with behavior supporting change. The path coefficient obtained from the relationship between the individual variables readiness to change to behavior to support to change is 0.70 with a tstatistic value of 8.56. At a significance level of alpha of 0.05 and 95 percent confidence level it can be said that there is a significant effect between individual readiness to change on behavior to support to change. The positive value of the parameter coefficient means that the more prepared the individual is in facing change, the more will encourage individual behavior to support change. This indicates that hypothesis 3 is supported.

Hypothesis 4 of this study is the commitment to change has a positive relationship with the readiness of individuals to change. Based on the path coefficient equation obtained from the relationship between commitment to change to behavior to support to change of 0.22 with a t-statistic value of 2.39 . At a significance level of alpha of 0.05 and 95 percent confident level, it can be said that there is a significant effect between commitment to change on behavior to support to change. The positive value of the parameter coefficient means that the higher the commitment to change, the more will encourage behavior to support change. Hypothesis 4 is therefore supported.

\section{Sobel Test}

Sobel test is a test to find out whether a relationship through a mediating variable is significantly capable as a mediator in that relationship. The aim of this test is to know the extant the role of the first mediation variable in this case, Individual Readiness to Change and the second mediating variable is Commitment to Change.

Individual Readiness to Change mediates Change Oriented Leadership and Commiment to change Based on the above equation, using the $\mathrm{z}$ value of the sobel test is 7.81 is this value is more of $\mathrm{z}$-score so that it can be concluded that change-oriented leadership can encourage commitment to change by increasing the individual's readiness to change first.

\section{Individual Readiness to Change mediates Change Oriented Leadership and Behavior Support to} change

Based on the above equation, the $\mathrm{z}$ value of the sobel test is 6.81 is, this value is more than the $\mathrm{z}$-score so that it can be concluded that change-oriented leadership can encourage behavior to support change by increasing the readiness of individuals to change first

\section{Commitment to Change mediates Individual Readiness to Change to Behavior support to change}

Based on the above equation, the $\mathrm{z}$ value of the sobel test obtained a value of 2.36, this value is more of $\mathrm{z}$ score hence, it can be concluded that the readiness of individuals to change can encourage behavior to support change by increasing their commitment to change first.

\section{Discussion}

Behavior support to change is significantly influenced by the readiness of individuals to change and commitment to change. Of these two factors, the readiness of individuals to change is the most dominant factor. While commitment to change positively and significantly this variable is also influenced by the individual readiness to change. An individual's readiness to change is greatly influenced by change- 
International Journal of Economics, Business and Accounting Research (IJEBAR)

Peer Reviewed - International Journal

Vol-3, Issue-4, 2020 (IJEBAR)

E-ISSN: 2614-1280 P-ISSN 2622-4771

https://jurnal.stie-aas.ac.id/index.php/IJEBAR

oriented leadership. Individual readiness to change becomes an important factor both to encourage commitment to change and behavior support to change. This is in accordance with the theory of behavior change conveyed by Lewin (1997) that individual behavior can change if there is an imbalance between the driving force and the restraining power within a person. When the driving force increases and the restraining power can be lowered, there will be a change in behavior towards the driving force, in this case the driving force of behavior supporting change is the readiness of individuals to want to change and individual commitment to change, and the support of leaders who are oriented change. This result is also consistent with the research conducted by Indriastuti and Fachrunnisa (2019) which shows that changed oriented leadership have a positive influence of the employee to be ready to face change.

Individual readiness to change has a significant effect on employee behavior support to change, this is in accordance with research conducted by Armenakis, Harris and Mossholder (1993) that individual readiness to change will affect one's beliefs, intentions, and attitudes about the extent to which change is needed in an organization to successfully make these changes. Individuals who are ready to face changes later tend to be able to adapt to changes so that the results can suppress the amount of resistance.

Individual readiness significantly influences the commitment to change, mainly influenced by his willingness to follow new work procedures. Individual readiness to change will be realized through the extent to which the individual is ready both mentally-psychologically, or physically, and wants to participate in organizational development activities (Hanpachern, 1997). Thus, it can be concluded that employees who are ready to face changes will have a willingness to follow organizational changes, which means that individuals will also have a strong commitment to change, because the true commitment to change is a willingness to do something and the strength of a binding mindset individuals to carry out an action deemed necessary for the successful implementation of change (Herscovitch \& Meyer 2002). Hence the more prepared the individual is to deal with change the stronger his commitment to dealing with change.

Change-oriented leadership has a positive influence on an individual's readiness to change, primarily the ability to explain to subordinates the importance of following change and development. The leadership element becomes an important factor in an organization, because leadership can influence and direct employees to achieve organizational goals. Change-oriented leadership will help direct, monitor and empower individuals to be ready to adapt in the face of change so that the goals of change can be achieved.

\section{Conclusion}

Research on the best way to prepare employee to support organizational changes has been conducted and it can be concluded that to encourage behavior support to change organization must manage the readiness of individuals and their commitment to change, the way to grow employee commitment to change is to prepare individuals to change first, and the way to increase the individual's readiness to change is with the strong encouragement of the leader who also has an orientation toward change.

Some suggestions that arise are that leaders should give more examples and role models in everyday attitudes and behavior. Leaders must be able to communicate change initiatives to employees, provide clarity about how this change process will take place, what challenges will be faced and what benefits will be felt if employees follow the flow of change. Additionally, leaders must also be able to encourage a sense of have and joint involvement among employees, since the process of change is the responsibility of all parties.

Management needs to increase the motivation and confidence of employees to be better prepared to face changes, among others by providing training that can support the demands of work such as training using software stata, amos, eviews, lisrel (for data analysis), and supported by training to disseminate data such as infographic, videographic, public speaking and journalistic training. Besides increasing 
International Journal of Economics, Business and Accounting Research (IJEBAR)

Peer Reviewed - International Journal

Vol-3, Issue-4, 2020 (IJEBAR)

E-ISSN: 2614-1280 P-ISSN 2622-4771

https://jurnal.stie-aas.ac.id/index.php/IJEBAR

knowledge sharing activities through social media such as LWAG (Whats App Group Lecture), which can increase knowledge and insight so that employees become more confident in facing the demands of society in this changing era.

Giving appreciation from the leadership to employees who succeeded in carving achievements and creating innovation becomes an important thing, because it can increase individual commitment to want to change. Employees will be encouraged to follow the changes because there is a reward they will receive if they can change according to organizational goals it can be financial such as incentive or bonuses or non-financial such as promotion, recognition and awards.

The management is expected to be able to encourage behavior support to change, especially the willingness to fight for change/Championing from employees, by increasing role and number of agents of change, monitoring and seeing which employees have positive perceptions and behaviors about change to be recruited as agents of change so that they can transmit the energy positive to other employees who still have negative perceptions about change, because in essence all individuals in the organization can act as agents of change.

This study certainly has several limitations, one of which is that this study only uses a soft system approach (an approach that originates from within the individual itself) to measure the Individual Readiness to Change variable. Therefore, future studies should measure the Individual Readiness to Change variable by using both soft and hard system approaches, consequently it is not only measured through the approach from within the individual, but also measured through hard system approaching work systems, work tools and work structures that are support towards individual readiness for organizational change.

\section{References}

Ajzen. (1991). The theory of planned behavior. Organizational behavior and human decision process 50 (2), 179-211

Al-Abbrow, H (2013). Individual differences as a moderator of the effect of organizational commitment on readiness for change. International Journal of Mangement, Vol 30 no 4

Armenakis, A.A., Harris, S.G., \& Mossholder, K.W. (1993). Creating Readiness for Organizational Change. Human Relation, 46(6), 681-703. https://doi.org/10.1177/001872679304600601

Armenakis, Achilles \& Bernerth, Jeremy \& Pitts, Jennifer \& Walker, H.. (2007). Organizational Change Recipients' Beliefs Scale. The Journal of Applied Behavioral Science. 43. 481-505. $10.1177 / 0021886307303654$.

Armenakis, Field, Hold \& Harris. (2007). Readiness for organizational change: The systematic development of a scale. The Journal of applied behavioral science 43 (2) 232-255

Blackman, D., Buick, F., O’Donnell, M., O'Flynn, J. and West, D. (2013), Strengthening the Performance Framework: Towards a High Performing Australian Public Service, Australian Public Service Commission, Canberra.

Coetsee, L (1999), "From Resistance to Commitment", Academic Journal Article, Vol.23, No.2

Corner, D. R. (1992). Managing at the speed of change. New York: Villard Books Random House, Inc.

Cumming \& Worley, (2001). Organization Development and Change. South Western Collage Publication.

Desplaces, D. (2005). A Multilevel Approach to Individual Readiness to Change. The Journal of

Behavioral and Applied Management, 7 (1), 25-39

Fumasoli, T., Stensaker, B. Organizational Studies in Higher Education: A Reflection on Historical

Themes and Prospective Trends. High Educ Policy 26, 479-496 (2013).

https://doi.org/10.1057/hep.2013.25 
International Journal of Economics, Business and Accounting Research (IJEBAR)

Peer Reviewed - International Journal

Vol-3, Issue-4, 2020 (IJEBAR)

E-ISSN: 2614-1280 P-ISSN 2622-4771

https://jurnal.stie-aas.ac.id/index.php/IJEBAR

Gelaidan, (2013). The Factor effecting employee commitment to change in public sector: Evidence from Yemen. International Business Research.

Hair et al. (2010). Multivariate Data Analysis (7th Ed.) Boston: Pearson

Hanpachern, C., Morgan, G.A., Griego, O.V. (1998). An Extention of The Theory of Margin: A Framework for Assesing Readiness for Change. Human Resources Development Quarterly. 9 (4):339350

Herscovitch, L., \& Meyer, J. P. (2002). Commitment to organizational change: Extension of a threecomponent model. Journal of Applied Psychology, 87(3), 474-487. https://doi.org/10.1037/00219010.87.3.474

Huy, Q. N. (1999). Emotional capability, emotional intelligence, and radical change. Academy of Management Review, 24(2), 325-345.

Indriastuti, D., Fachrunnisa, O. (2019). Triple Psycho-Organizational Supports for Change Management Process. Interntional Journal of Economics, Business, and Accounting Research, Vol 3, No 04 (2019). http://dx.doi.org/10.29040/ijebar.v3i04.613

Juhdi, N., Pa'wan, F., \& Othman, N.A. (2011). HR practices, organizational commitment and turnover intention: a study on employees in Klang Valley, Malaysia.

Jones, R. A., Jimmieson, N. L., \& Griffiths, A. (2005). "The impact of organizational culture and reshaping capabilities on change implementation success: the mediating role of readiness for change." Journal of Management Studies, 42(2), 361-386

Kasali, R. (2007). Re-code Your DNA, Gramedia Pustaka Utama, Jakarta

Kreitner, R., \& Kinichi, A. (2007). Organizational behavior (Vol. 7th ed). Avenues of The Americas, New York: McGraw Hill.

Lewin, K., \& American Psychological Association. (1997). Resolving social conflicts: \&, Field theory in social science. Washington, DC: American Psychological Association.

Luthans, F. (2002), "Positive organizational behavior: Developing and managing psychological strengths," Academy of Management Executive, 16, 57-72.

Muafi, Fachrunnisa, O., Siswanti, Y. et al. Empowering Leadership and Individual Readiness to Change: the Role of People Dimension and Work Method. J Knowl Econ 10, 1515-1535 (2019). https://doi.org/10.1007/s13132-019-00618-z

Mullins, L. J. (2005). Management and Organizational Behavior Bristol: Prentice Hall

Prochaska, J., \& DiClemente, C. (1984). The transtheoretical approach: Crossing traditional boundaries of therapy , Ill., (Vol. III). Homewood Dow Jones-Irwin

Qais, A.A., Rezian-na, M.K., Valliapan, R., Ali, A., \& Muhammed, A.(2018). Factor Affecting Individual Readiness for Change: A Conceptual Framework. International Journal Of Management and Human Science, 2(1), 13-18, Retrieved from https://ejournal.lucp.net/index.php/ijmhs/aticle/view/827

Visagie, C.M., \& Steyn, C. (2011). Organisational commitment and responses to planned organisational change: An exploratory study.

Weiner, BJ. (2009), A Theory of organizational readiness for change. Implementation Sci 4, 67 (2009) doi:10.1186/1748-5908-4-67

Yukl G Gordon A \& Taher (2002), A Herarchical Taxonomy of Leadership Behavior Integrating a Half Century of Behavior Research. Journal of Leadership and Organizational Studies, 15-32.

Yukl, G. (2013), Leadership in Organizations, Pearson, Boston 